\title{
Proces suburbanizacji a powstawanie nowych parafii. Przykład aglomeracji poznańskiej
}

\author{
The process of suburbanisation and the formation of \\ new parishes. The example of Poznan agglomeration
}

\begin{abstract}
The process of suburbanization has been recently one of the main topics discussed by geographers as well as other scholars from disciplines interested in urban issues. As people and companies relocate to the suburbs, it becomes necessary to supply new roads, schools, shops and many other facilities. Sometimes suburbanisation also leads to the construction of new churches, especially in Poland, where a large part of the society still actively participates in the religious practices of the Roman Catholic Church. The aim of this paper is to investigate the relationship between the process of suburbanisation and the formation of new catholic parishes using the case of Poznan agglomeration in which suburbanisation processes have been particularly intensive in the last years. Results show that a significant number of new parishes were grounded in the city of Poznan and its suburbs in the period between 1990 and 2013, and that the formation of some of these parishes can be attributed to the process of suburbanisation. The paper also contains a discussion of arguments for and against the formation of new parishes in the suburbs. It has been argued by some that large urban parishes can better respond to spiritual needs of people than small suburban parishes, and that the construction of new churches in the times of crisis should be avoided in favour of charity. On the other hand, spatial proximity of the church is very likely an important factor for many persons, so every case should be considered separately. Since the process of suburbanisation in Poznań agglomeration will definitely continue in the coming years, the formation of new catholic parishes in the suburbs is also likely to take place.
\end{abstract}

Keywords: suburban, agglomeration, parish, Poznań 


\section{Wprowadzenie}

Proces suburbanizacji w ostatnich latach bardzo często był przedmiotem zainteresowania geografów, jak również przedstawicieli innych dziedzin (Beim 2009, Jakóbczyk-Gryszkiewicz 1998, Kajdanek 2012, Liszewski 1987). Jest to, najogólniej rzecz ujmując, proces związany z przenoszeniem się ludności oraz przedsiębiorstw na obszary położone na peryferiach miast. Suburbanizacja prowadzi do pojawienia się różnego rodzaju nowych potrzeb w miejscach, gdzie wcześniej ich było lub występowały tylko marginalnie. Przedmieścia (inaczej: suburbia) w krótkim czasie przeobrażają się z obszarów o raczej wiejskim charakterze w typowe środowisko zurbanizowane. Powstają nowe przedszkola, szkoły, sklepy, miejsca sportu i rekreacji. Mimo to zdarza się, że na nowych osiedlach brak jest pewnych istotnych z punktu widzenia mieszkańców obiektów lub infrastruktury. Skutkiem tego jest korzystanie miejskich szkół czy też placówek handlowych. Bywa też, że osiedle podmiejskie traktowane jest tylko jako „sypialnia”, natomiast miejscem zaspokajania wszystkich istotnych potrzeb jest miasto.

We wszelkich rozważaniach typu „co jest, czego nie ma, a co powstaje na przedmieściach" rzadko brane są pod uwagę obiekty sakralne. Wątek ten przewija się wprawdzie niekiedy $\mathrm{np} . \mathrm{w}$ artykułach prasowych, lecz na ich podstawie trudno oszacować czy chodzi o zjawisko masowe, czy też marginalne - tym bardziej, że ton tychże artykułów jest często dość tendencyjny. Powstawanie nowych parafii i kościołów na przedmieściach miast jest faktem, jednakże nasza wiedza na ten temat jest dość ograniczona.

Celem niniejszego artykułu jest ukazanie tego zjawiska od strony naukowej, a w szczególności próba odpowiedzi na pytanie, jaki jest związek pomiędzy procesem suburbanizacji a powstawaniem nowych parafii Kościoła rzymskokatolickiego. Studium przypadku stanowi aglomeracja poznańska, która na tle kraju odznacza się ponadprzeciętnie wysokim natężeniem procesu suburbanizacji (Strategia rozwoju... 2011: 28). W artykule wykorzystano dane pochodzące z opracowania Instytutu Statystyki Kościoła Katolickiego (Wykaz parafii... 2006) oraz z zestawienia informacji o parafiach, zamieszczonego na stronie internetowej archidiecezji poznańskiej według stanu na sierpień 2014 r. (www 1). Wykorzystano także informacje pochodzące m.in. ze stron internetowych parafii oraz artykułów prasowych. 


\section{Parafia jako element struktury przestrzennej}

W wielu miastach gotycka katedra jest nie tylko wyrazistą dominantą urbanistyczną, ale też świadectwem doniosłej roli, jaką w przeszłości w życiu społecznym odgrywało chrześcijaństwo. Współcześnie tendencje sekularyzacyjne doprowadziły do pewnego wyparcia religii z przestrzeni publicznej. Pomimo to w dzisiejszym świecie wiara i religia pozostają ważną częścią życia wielu osób. Społeczeństwo polskie odznacza się na tle Europy ponadprzeciętnie wysokim zaangażowaniem religijnym, wciąż znaczna liczba osób uczestniczy w katolickich praktykach religijnych ${ }^{1}$.

Zasadniczym miejscem, w którym realizowane są praktyki religijne jest kościół parafialny. Parafia to - obok diecezji - podstawowa jednostka podziału terytorialno-administracyjnego Kościoła. Istotą parafii jest umożliwienie bezpośredniego kontaktu pomiędzy wiernymi a duszpasterzem. Według stanu na koniec 2005 r. istniało w Polsce ponad 10 tys. parafii rzymskokatolickich (Wykaz parafii... 2006: 5). Zarówno zasięg terytorialny, jak i liczba wiernych są w poszczególnych parafiach bardzo zróżnicowane. Przeciętna liczba wiernych przypadających na jedną parafię w diecezjach „wielkomiejskich”, takich jak warszawska czy łódzka, przekracza 6 tys., natomiast w diecezjach o raczej wiejskim charakterze, takich jak przemyska czy drohiczyńska, jest to około 2 tys. (Adamczuk i Zdaniewicz 2006: 46-47). W dużych miastach spotyka się parafie liczące nawet ponad 10 tys. wiernych.

Po upadku socjalizmu zniesione zostały obowiązujące wcześniej ograniczenia dotyczące budowy kościołów, a liczba parafii w Polsce zaczęła wzrastać w szybszym tempie. W okresie od 2003 do 2006 r. powstało ponad 100 nowych parafii (Wykaz parafii... 2006: 5). Pojawiły się w związku z tym głosy, iż w obliczu postępujących procesów sekularyzacyjnych tworzenie kolejnych placówek jest bezzasadne. Tym niemniej należy zauważyć, że dla znaczącej części polskiego społeczeństwa parafia była i jest ważną instytucją. W świetle wyników przeprowadzonej przed kilkunastu laty ogólnopolskiej ankiety ponad połowa (55\%) respondentów stwierdziła, że czuje się związana z parafią, natomiast $29 \%$ badanych

\footnotetext{
${ }^{1}$ Według badań Instytutu Statystyki Kościoła Katolickiego wskaźnik dominicantes, wyrażający odsetek wiernych uczestniczących w niedzielnej mszy św., zmniejszył się z 47\% w 1992 r. do 41\% w 2010 r. Natomiast wskaźnik communicantes, będący miarą przystępowania do komunii świętej, wzrósł w tym samym okresie z 14\% do $16,4 \%$ (www 2).
} 
zadeklarowało częściowy związek (Firlit 2004: 150). W 2012 r. niemal połowa ankietowanych Polaków (47,5\%) potwierdziła systematyczność praktyk religijnych, a dalsze 26,5\% określiło się jako praktykujący niesystematycznie (Rocznik statystyczny Kościoła katolickiego w Polsce 2014: 168).

Studia nad przestrzennym rozmieszczeniem parafii są obecne w nurcie badawczym polskiej geografii religii już od pewnego czasu. Na uwage zasługują m.in.: artykuły Przestrzenne zróżnicowanie rozwoju sieci parafii $w$ regionie przemysłowym (Domański, Gwosdz i Luchter 2005), Parafia jako przedmiot zainteresowania geografii - doświadczenia łódzkie (Klima 2011) oraz książka Zróżnicowanie przestrzeni sakralnej Gdyni (Przybylska 2008). Nie są natomiast znane autorowi niniejszego artykułu żadne polskie opracowania dotyczące związku pomiędzy procesem suburbanizacji a powstawaniem nowych parafii. Po części może wynikać to z faktu, iż w przypadku niektórych miast związek taki nie występuje, bądź też dopiero się uwidacznia. W cytowanym powyżej studium przypadku Łodzi stwierdzono, że trudno doszukać się zdecydowanych przestrzennych prawidłowości $w$ rozmieszczeniu najmłodszych parafii (Klima 2011: 238).

Również w literaturze zagranicznej trudno znaleźć opracowania dotyczące tego tematu. W przypadku krajów Europy Zachodniej uwagę zdają się przyciągać raczej przypadki zamykania kościołów i przeznaczania dawnych budowli sakralnych na inne cele. Jednak także w krajach bardziej zsekularyzowanych niż Polska powstanie nowego osiedla wiąże się niekiedy z budową nowego kościoła. Przykładem może być powstałe w latach 90. ubiegłego stulecia osiedle Rieselfeld we Fryburgu Bryzgowijskim (Niemcy). W centrum nowej dzielnicy została wybudowana świątynia, który służy dwóm wspólnotom wyznaniowym: katolickiej i ewangelickiej (www 3). W tym miejscu należy wspomnieć także o specyficznej formie prowadzenia działalności duszpasterskiej na przedmieściach, która zdaje się występować głównie w Stanach Zjednoczonych. Jest to tzw. drive-in church, a zatem kościół, w którym wierni uczestniczą w nabożeństwie, siedząc we własnych samochodach ${ }^{2}$.

\footnotetext{
${ }^{2}$ Kościoły takie znajdują się m.in. w Daytona Beach (Floryda) oraz Woodland (Michigan) (www 4).
} 


\section{Proces suburbanizacji w aglomeracji poznańskiej}

Aglomeracja poznańska zalicza się do największych obszarów zurbanizowanych w Polsce, przy tym należy zaznaczyć, że zarówno w opracowaniach naukowych, jak i w sferze praktycznej spotyka się różne delimitacje jej zasięgu (por. Parysek 2008, Swianiewicz i Klimska 2005, Strategia rozwoju... 2011). Często spotykanym w praktyce rozwiązaniem kompromisowym wydaje się przyjęcie, że aglomeracja poznańska obejmuje miasto Poznań oraz otaczający je powiat poznański, w skład którego wchodzi 17 gmin, w tym dwie miejskie, osiem miejsko-wiejskich i siedem wiejskich.

Na obszarze aglomeracji poznańskiej zachodzi proces suburbanizacji typu ekstensywnego, polegający na powstawaniu na terenach podmiejskich głównie osiedli zabudowy jednorodzinnej o niskiej intensywności. W literaturze przedmiotu tego rodzaju zjawisko zwykło się określać mianem rozlewania się miast (ang. urban sprawl). Przyjmuje się, że ekstensywna suburbanizacja rozpoczęła się w Polsce po upadku ustroju socjalistycznego, natomiast w ostatnich latach proces ten uległ wyraźnemu nasileniu w związku ze wzrostem stopnia zamożności i mobilności społeczeństwa. Suburbanizacja w aglomeracji poznańskiej przejawia się powolnym, lecz systematycznym spadkiem liczby mieszkańców Poznania oraz wzrostem zaludnienia w gminach sąsiednich. Co charakterystyczne, przyrost liczby ludności w gminach powiatu poznańskiego jest bardzo zróżnicowany. Biorąc pod uwage okres od 1995 do 2012 r., w niektórych gminach liczba ludności wzrosła zaledwie o kilka procent, podczas gdy w innych o kilkadziesiąt (ryc. 1). W jednej z gmin nastąpiło nawet podwojenie liczby mieszkańców. Taka sytuacja wynika z faktu, iż poszczególne części aglomeracji charakteryzują się zróżnicowaną atrakcyjnością dla celów osiedleńczych, co z kolei jest pochodną szeregu czynników - dostępności komunikacyjnej, atrakcyjności krajobrazu i innych.

Powstawanie nowych osiedli na przedmieściach Poznania ma bardzo żywiołowy i w dużej mierze niekontrolowany charakter. Zgodnie z obowiązującym prawem lokalizacja nowej zabudowy powinna następować w oparciu o miejscowy plan zagospodarowania przestrzennego. Jednakże plany zostały uchwalone przez rady gmin tylko dla części obszarów, co skutkuje wydawaniem decyzji o warunkach zabudowy. Podstawowym kryterium jest w tym przypadku 


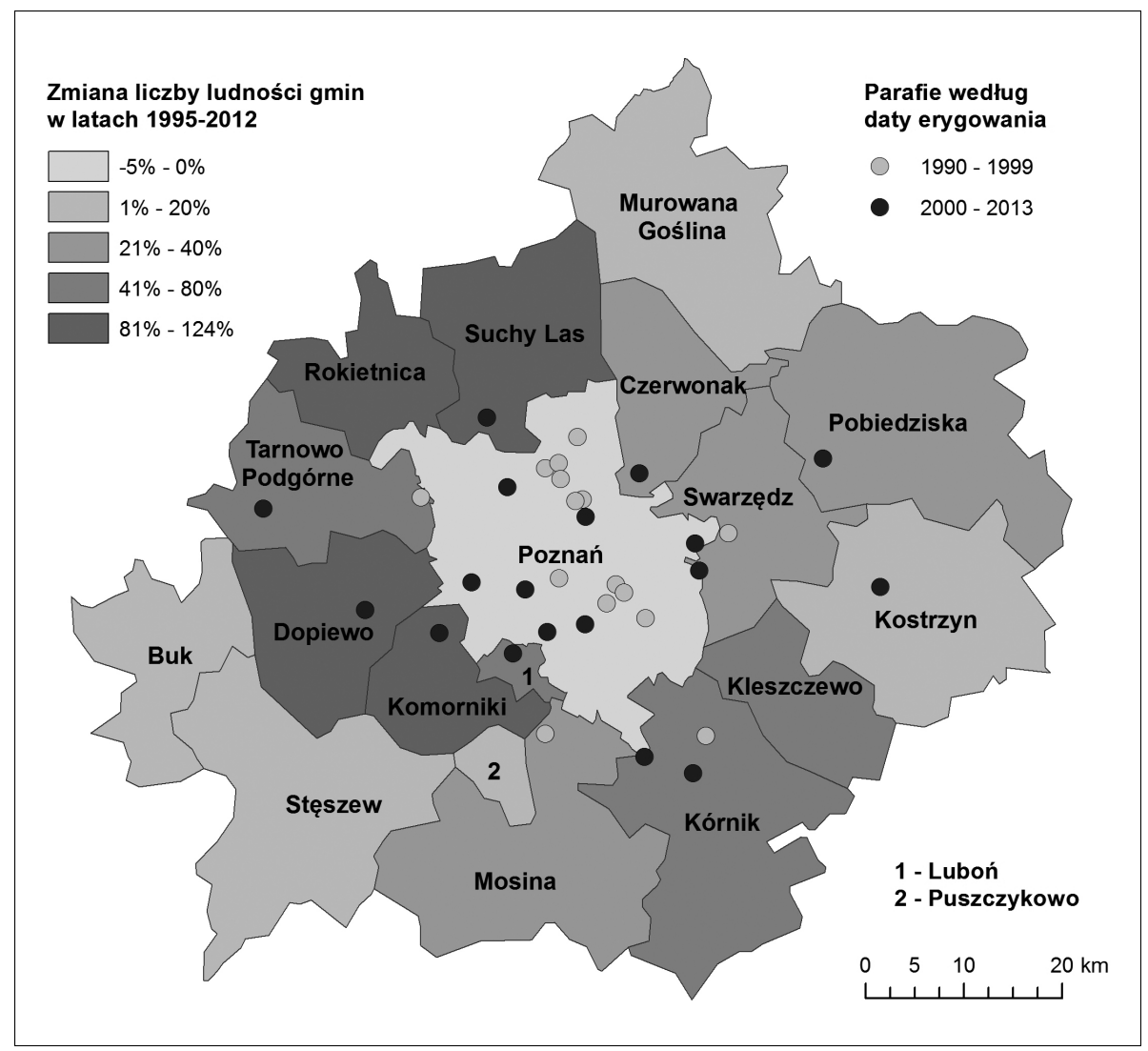

Ryc. 1. Nowo erygowane parafie na tle zmiany liczby ludności w Poznaniu i gminach powiatu poznańskiego

Źródło: opracowanie własne na podstawie Wykazu parafii w Polsce (2006), strony internetowej archidiecezji poznańskiej oraz danych GUS.

zasada tzw. dobrego sąsiedztwa, która w praktyce pozostawia deweloperom znaczną swobodę decyzji odnośnie lokalizacji i intensywności zabudowy. Brak długookresowych planów rozwoju gmin utrudnia realizację różnego rodzaju inwestycji, gdyż trudno jest chociażby przewidzieć, ile osób będzie mieszkać na danym obszarze za 10 czy 20 lat. 


\section{Nowe parafie w aglomeracji poznańskiej}

Na potrzebę tworzenia nowych parafii na obszarach podmiejskich Poznania wskazał arcybiskup metropolita Stanisław Gądecki w liście pasterskim skierowanym do wiernych w 2006 r. Podane zostały nawet konkretne lokalizacje nowych świątyń.

„(...) W dziedzinie budowy świątyń wciąż stają przed Archidiecezją nowe zadania. Powstają nowe osiedla, a wraz z nimi rosną potrzeby duszpasterskie. Kościół ciągle się rozwija, a to wymaga nowych domów Bożych. Pilną ich potrzebę widzimy szczególnie na obrzeżach Poznania, w rejonie miejscowości: Kamionki i Daszewice, Dąbrówka i Palędzie, Suchy Las i Jelonek, Zalasewo i Garby k. Swarzędza, Kiekrz i Rokietnica. Są też potrzeby w samym Poznaniu, a także w Kostrzynie, Kościanie, Lesznie, Śremie, Szamotułach i Nowym Tomyślu" (www 5).

Mając na uwadze powyższe stwierdzenia, można założyć, że tworzenie nowych parafii w związku z zachodzącymi procesami suburbanizacji stało się elementem swego rodzaju „strategii rozwoju” archidiecezji poznańskiej.Obszar badań przyjęty dla celów niniejszego opracowania obejmuje 16 dekanatów ${ }^{3}$ archidiecezji poznańskiej (ryc. 2). W tej liczbie znajduje się osiem dekanatów, które w całości lub w przeważającej części leżą na obszarze miasta Poznania. Są to: Jeżyce, Łazarz, Nowe Miasto, Piątkowo, Rataje, Stare Miasto, Starołęka, Winogrady. Kolejne dekanaty, a mianowicie: bukowski, czerwonacki, kostrzyński, Luboń, przeźmierowski, stęszewski i swarzędzki, mają swoją siedzibę na obszarze powiatu poznańskiego. Osiem dekanatów poznańskich pokrywa się w przybliżeniu z zasięgiem terytorialnym miasta Poznania, są jednak pewne rozbieżności. Nieliczne parafie poznańskie przynależą do dekanatów spoza Poznania i vice versa. W opracowaniu nie uwzględniono fragmentu aglomeracji poznańskiej należącego do archidiecezji gnieźnieńskiej (jest to w przybliżeniu obszar gmin Murowana Goślina i Pobiedziska). Pomimo to obszar badań obejmuje swym zasięgiem przeważającą część aglomeracji poznańskiej, rozumianej jako miasto Poznań wraz z sąsiadującym z nim powiatem poznańskim.

Według stanu na koniec 2013 r. w skład dekanatów poznańskich wchodziło 65 parafii, natomiast w dekanatach, które miały swoją siedzibę na terenie powiatu poznańskiego, było ogółem 77 parafii. Pomimo iż brak jest dokładnych danych o liczbie mieszkańców ośmiu dekanatów podmiejskich, zapewne jest ona mniejsza

${ }^{3}$ Dekanat to jednostka obejmująca w przybliżeniu 10 parafii. 


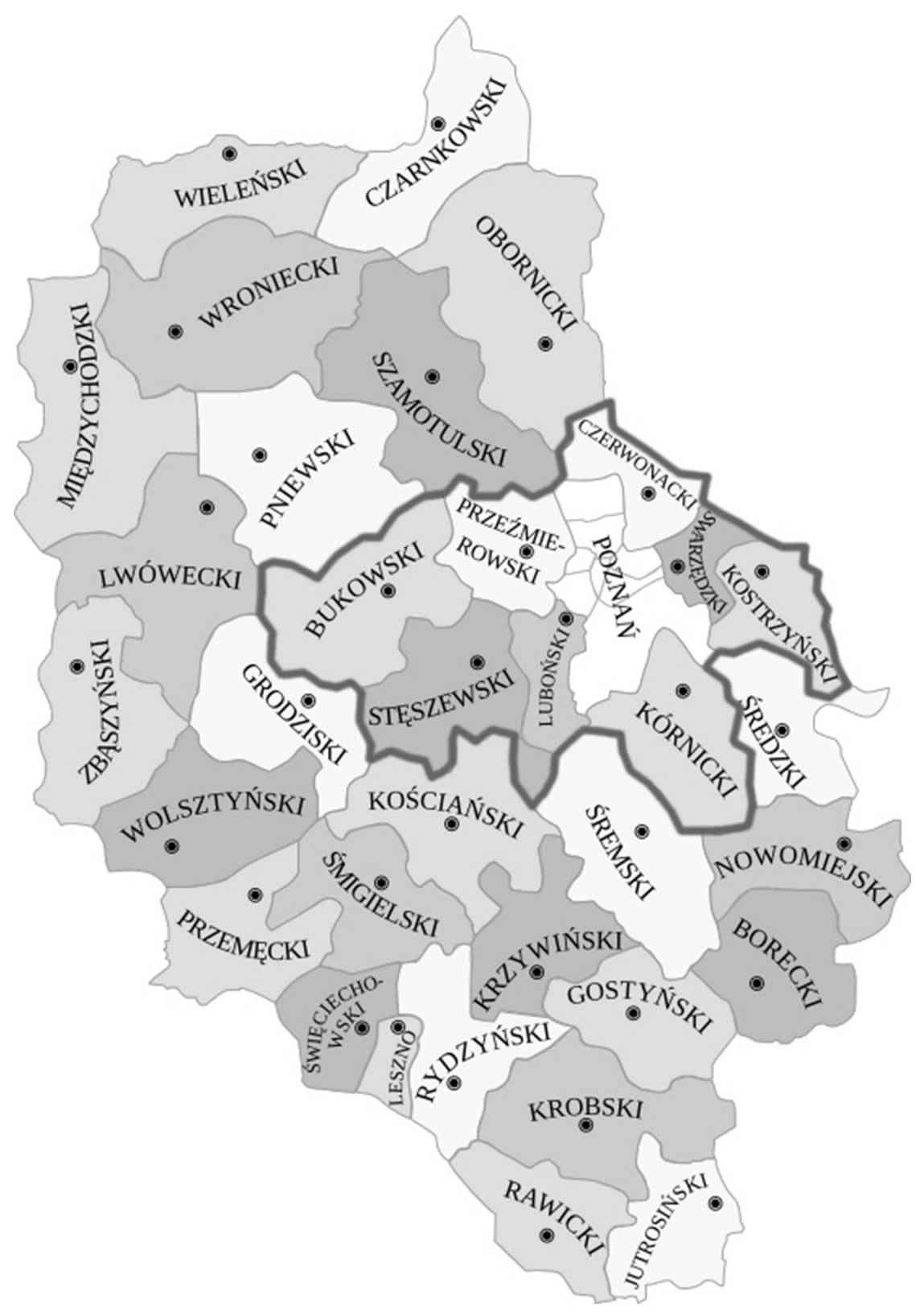

Ryc. 2. Położenie dekanatów uwzględnionych w badaniu empirycznym w granicach archidiecezji poznańskiej

Źródło: opracowanie własne, podkład kartograficzny: http://www.archpoznan.pl/component/ option,com_map/. 
niż liczba mieszkańców Poznania, natomiast liczba parafii na przedmieściach jest większa niż w mieście. Można z tego wywnioskować, iż przeciętna liczba mieszkańców przypadających na jedną parafię w Poznaniu była większa niż na terenach podmiejskich. Łączna liczba parafii w dekanatach poznańskich i podmiejskich wynosiła 142 .

W okresie od 1990 do 2013 r. w dekanatach poznańskich powstało 21 nowych parafii (tab. 1, ryc. 1). Ich liczba w poszczególnych dekanatach była dość mocno zróżnicowana. Przykładowo w dekanacie Jeżyce nie powstała żadna nowa parafia, natomiast najwięcej nowych erygowano w dekanatach obejmujących swym zasięgiem głównie osiedla wielkopłytowe: Rataje, Winogrady i Piątkowo. W sumie w tych trzech dekanatach utworzono aż 13 parafii. Powstanie większości z nich traktować należy w kategoriach „nadrabiania zaległości” z czasów PRL-u. Choć powszechnie znane są przede wszystkim kłopoty z budową kościoła w Nowej Hucie, nie był to bynajmniej odosobniony przypadek. Generalnie budowa kościołów była przez władze socjalistyczne utrudniana, a dotyczyło to w szczególności osiedli wielkopłytowych, które miały być symbolami „nowego porządku”. Na poznańskich osiedlach wielkopłytowych istniało wprawdzie przed 1990 r. kilka parafii, jednakże w kolejnych latach nastąpiło znaczące „dogęszczenie”. Wśród nowych parafii powstałych po 1990 r. znajduje się m.in. parafia pw. św. Karola Boromeusza (dekanat Winogrady), patrona Karola Wojtyły, erygowana w 2007 r. jako wotum wdzięczności za pontyfikat papieża Jana Pawła II. Swego rodzaju ciekawostką jest natomiast fakt, iż na piątkowskim osiedlu Bolesława Śmiałego powstała parafia, której patronem jest św. Stanisław Biskup i Męczennik.

Powstawanie nowych parafii w dekanatach poznańskich związane było jednak nie tylko z nadrabianiem zaległości z okresu socjalizmu, lecz także z nowymi procesami osiedleńczymi. Przykładem tego jest erygowana w 2009 r. parafia pw. św. Joanny Beretty Molli, która formalnie przynależy do dekanatu Poznań-Piątkowo, lecz swoim zasięgiem obejmuje podmiejskie osiedle Złotniki (gmina Suchy Las). Natomiast powstała w 2004 r. parafia pw. św. Ojca Pio, będąca częścią dekanatu Poznań-Winogrady, zlokalizowana jest w Strzeszynie, osiedlu o podmiejskim charakterze położonym na peryferiach Poznania. Z kolei jedną z najmłodszych jest parafia pw. Matki Teresy z Kalkuty, utworzona w 2012 r., która nie posiada jeszcze własnego kościoła. Parafia ta jest częścią dekanatu Poznań-Starołęka, natomiast jej siedzibą jest podpoznańska miejscowość Kamionki.

W ośmiu dekanatach podmiejskich w latach 1990-2013 utworzono 12 nowych parafii. Jest to liczba mniejsza niż w przypadku dekanatów poznańskich, lecz także znacząca. Powstanie większości z tych parafii można interpretować jako 
skutek procesu suburbanizacji, a do pewnego stopnia także jako antycypację przyszłych zmian w strukturze osiedleńczej. Najwięcej nowych parafii, bo aż cztery, erygowano w dekanacie przeźmierowskim. Powstały one w miejscowościach: Baranowo, Dąbrówka, Lusówko i Plewiska, których nazwy dość jednoznacznie kojarzą się z procesem suburbanizacji w aglomeracji poznańskiej. Z kolei w dekanatach bukowskim oraz stęszewskim w analizowanym okresie nie powstała żadna nowa parafia. Wiązać to można z faktem, iż dekanaty te położone są w większej odległości od Poznania, na obrzeżach powiatu poznańskiego. W pozostałych dekanatach podmiejskich utworzono od jednej do trzech nowych parafii (tab. 1).

Tab. 1. Istniejące oraz nowo erygowane w latach 1990-2013 parafie na obszarze badań

\begin{tabular}{|l|c|c|}
\hline \multicolumn{1}{|c|}{ Dekanat } & Liczba parafii ogółem & $\begin{array}{c}\text { Liczba parafii erygowanych } \\
\text { w latach 1990-2013 }\end{array}$ \\
\hline Poznań-Jeżyce & 11 & 2 \\
\hline Poznań-Lazarz & 9 & 1 \\
\hline Poznań-Nowe Miasto & 8 & 5 \\
\hline Poznań-Piątkowo & 8 & 4 \\
\hline Poznań-Rataje & 9 & 2 \\
\hline Poznań-Stare Miasto & 12 & 3 \\
\hline Poznań-Starołęka & 8 & 4 \\
\hline Poznań-Winogrady & 8 & 21 \\
\hline Suma (I) & 65 & 0 \\
\hline Bukowski & 10 & 1 \\
\hline Czerwonacki & 7 & 2 \\
\hline Kórnicki & 9 & 1 \\
\hline Kostrzyński & 10 & 12 \\
\hline Luboń & 10 & 4 \\
\hline Przeźmierowski & 12 & 0 \\
\hline Stęszewski & 10 & 3 \\
\hline Swarzędzki & 9 & 17 \\
\hline Suma (II) & 142 & 2 \\
\hline Suma (I+ II) & & 2 \\
\hline
\end{tabular}

Źródło: opracowanie własne na podstawie danych Instytutu Statystyki Kościoła Katolickiego SAC oraz archidiecezji poznańskiej. 
Przebieg procesu powstawania podmiejskiej parafii można prześledzić na przykładzie parafii pw. św. Rity w Lusówku. Jest to miejscowość położona nad Jeziorem Lusowskim, w bliskim sąsiedztwie powstającej zachodniej obwodnicy Poznania (trasa S11), co poniekąd predestynuje ją do roli osiedla podmiejskiego. Proces tworzenia parafii rozpoczął się w sierpniu 2013 r., wraz z powierzeniem nowo powołanemu proboszczowi funkcji wikariusza parafii w sąsiednim Lusowie oraz zadania zakładania parafii w Lusówku (www 6). Z formalnego punktu widzenia parafia powstała w dniu 1 stycznia 2014 r. zgodnie z postanowieniem zawartym w dekrecie metropolity poznańskiego. Jest to zatem na chwilę obecną (sierpień 2014 r.) najmłodsza parafia w aglomeracji poznańskiej i jedna z najmłodszych w Polsce. Pewne działania zmierzające do utworzenia parafii zostały jednak podjęte już wcześniej, a inicjatywa, według słów proboszcza, wyszła od samych mieszkańców: „Podczas jednej z wizytacji księdza Biskupa Zdzisława Fortuniaka przedstawiciele Lusówka wyrazili pragnienie, by w ich miejscowości powstał kościół. Odpowiedzią na tą prośbę jest posłanie mnie do Was z zadaniem organizacji parafii i wspólnego budowania Domu Modlitwy" (www 7).

$Z$ reguły formalnie erygowane parafie na początku nie posiadają żadnej niezbędnej infrastruktury (kościoła, domu parafialnego). Budowa kościoła jest bez wątpienia dużym obciążeniem finansowym dla każdej nowej parafii. Najpowszechniej chyba stosowanym rozwiązaniem jest wzniesienie w pierwszej kolejności tymczasowej kaplicy, która pozwala na odprawianie nabożeństw. W dalszej kolejności budowana jest świątynia i ewentualnie inne budynki, jak np. dom parafialny. Nowe parafie pozyskują fundusze na cele inwestycyjne przede wszystkim od swoich wiernych, choć zdarzył się też przypadek wsparcia parafii przez dewelopera ${ }^{4}$. Do wyjątków zalicza się parafia pw. św. Jana Pawła II w Luboniu (notabene jedna $z$ pierwszych parafii pod wezwaniem polskiego papieża), gdzie kościół został wzniesiony jeszcze przed formalnym utworzeniem parafii, jako tzw. kościół filialny. Po beatyfikacji Jana Pawła II erygowano parafię, której patronem został nowy błogosławiony.

4 Jedna z firm budujących osiedle w podpoznańskiej miejscowości dokonała darowizny działki oraz projektu budowlanego na rzecz parafii. Deweloper przekazał także gminie działkę pod budowę szkoły (www 8). 


\section{Dyskusja}

Powstawanie nowych parafii na obszarach podmiejskich spotyka się z jednej strony $z$ aprobatą, a z drugiej z krytyką ze strony niektórych osób i środowisk. Krytyka przybiera różnoraki charakter i pochodzi zarówno z samego Kościoła, jak i z kręgów pozakościelnych. Po pierwsze, tworzenie nowych, z reguły małych, parafii na obszarach podmiejskich bywa podawane w wątpliwość jako działanie nieskuteczne z punktu widzenia pracy duszpasterskiej. Można przytoczyć w tym kontekście opinię ks. Andrzeja Draguły, zdaniem którego, współcześnie nie istnieje już tak silny jak kiedyś związek wiernych z konkretną strukturą terytorialną (parafią). Cechą współczesnych czasów jest dążenie do tego, aby mieć możliwie jak największy wybór, co obrazuje wypieranie drobnego handlu przez sklepy wielkopowierzchniowe (supermarkety). Odpowiedzią Kościoła na tę tendencje winno być raczej tworzenie dużych struktur oferujących zróżnicowaną ofertę duszpasterską, tzw. superparafii, niż „rozdrabnianie” sieci parafialnej. Takie struktury są w stanie zaoferować bogatszy program duszpasterski, a przez to lepiej odpowiedzieć na potrzeby duchowe wiernych: „Zdaję sobie sprawę, iż natychmiast padnie tutaj kontrargument mówiący o zależności między religijnością wiernych a geograficzną bliskością kościoła. Owszem, zależność taka istnieje, jest ona jednak typowa dla religijności typu tradycyjnego, dziedziczonego. Że z erozją takiej zależności mamy dzisiaj do czynienia, widać choćby na przykładzie społeczności wiejskich. Nowi mieszkańcy podmiejskich wiosek-noclegowni nie chcą wcale tak bardzo integrować się z lokalną społecznością, także w wymiarze parafialnym, i wolą udać się do miasta, by uczestniczyć w bardziej „wystawnej” Eucharystii, która pozwoli im na jej głębsze, pełniejsze przeżycie" (Draguła 2003).

Drugi nurt krytyki pochodzi z kręgów świeckich i związany jest z dążeniem do ograniczenia roli Kościoła (bądź ściślej duchowieństwa) w sferze publicznej. W pewnym uproszczeniu argumentację tę można podsumować stwierdzeniem, że w Polsce jest zbyt dużo kościołów, a budowanie kolejnych jest zbędne z uwagi na postępujące procesy sekularyzacyjne. Taki pogląd w rozmowie z Gazeta Wyborcza wyraził socjolog religii Józef Baniak, którego zdaniem fundusze przeznaczane na budowę kościołów należałoby przeznaczyć na inne cele, przede wszystkim na pomoc dobroczynną.

„W Polsce jest za dużo świątyń, zwłaszcza w miastach. Z badań, w tym wykonanych przez Instytut Statystyki Kościoła Katolickiego, jasno wynika, że nasilają się wskaźniki katolików rezygnujących z kultu religijnego, także w parafiach wiejskich 
i w małych miastach. Zjawisko to dotyczy w szczególności młodzieży. Niedługo w istniejących świątyniach będzie luźno albo i wręcz pusto!" (www 9).

Z kolei wśród argumentów przemawiających za tworzeniem nowych parafii na terenach podmiejskich można wymienić w pierwszej kolejności ich rolę w integracji lokalnej społeczności. Przywołajmy w tym miejscu słowa proboszcza parafii, która w ostatnich latach powstała w jednej z podpoznańskich miejscowości: „Czasami powstaje pytanie: po co to wszystko? Przecież jest tyle parafii, kościołów (... ) pewnie jest dużo parafii, kościołów - ale parafia i kościół w Kamionkach będzie tylko jedna, będzie nasza" (www 10). Przytoczone słowa świadczą o tym, że sami duchowni mają świadomość, że nowe parafie mogą pełnić funkcje nie tylko stricte religijne. Co więcej, właśnie tego rodzaju „dodatkowe” funkcje, a także forma relacji pomiędzy duszpasterzem a parafianami, może zaważyć na tym, czy nowa parafia zostanie zaakceptowana, czy też odrzucona.

Funkcjonowanie jednej z parafii na obrzeżach Poznania zostało przed kilku laty opisane na łamach Przewodnika Katolickiego. Mowa o parafii pw. św. Ojca Pio powstałej w 2004 r. w Strzeszynie. Jest to położone w sąsiedztwie klina zieleni w północno-zachodniej części Poznania nowe osiedle domów wielorodzinnych i jednorodzinnych, które wciąż posiada potencjał rozwojowy. Z artykułu pt. Parafia przyszłości można wywnioskować, że parafia była w stanie stworzyć ofertę atrakcyjną dla znacznej części mieszkańców. Organizowano m.in. spotkania tematyczne ze znanymi osobami oraz spotkania dla rodziców.

„Powszechnie uważa się, że młodzi ludzie odchodzą od Kościoła. Parafia pw. św. o. Pio z Pietrelciny na Strzeszynie Greckim i os. Literackim w Poznaniu dowodzi, że może być inaczej. Osiemdziesiąt procent mieszkańców to ludzie młodzi z wyższym wykształceniem. W niedzielę do kościoła uczęszcza ponad czterdzieści procent parafian. To jedna z najmłodszych parafii w Poznaniu, zarówno jeśli chodzi o przekrój wiekowy mieszkańców, jak i czas powstania. Także jedna z niewielu, gdzie liczba chrztów (64 w 2005 r.) zdecydowanie przewyższa liczbę pogrzebów (10 w 2005 r.). Z ogólnej liczby 2800 mieszkańców do kościoła co niedzielę przychodzi ich ok. 1300" (Kubica 2006).

Na kwestię tworzenia nowych parafii na obszarach podmiejskich można spojrzeć także z urbanistycznego punktu widzenia. We współczesnej urbanistyce operuje się pojęciami takimi jak „miasto kompaktowe” czy też „miasto krótkich odległości”. Postulowane jest mieszanie różnych funkcji, aby najbliższe otoczenie dawało możliwość zaspokojenia jak największej liczby potrzeb. Modernistyczny paradygmat rozdziału funkcji czy też model miasta satelickiego traktowane są 
już raczej jako przeszłość. $Z$ tego punktu widzenia można skłaniać się raczej ku modelowi sieci małych parafii podmiejskich niż „superparafii” (przynajmniej rozumianej jako alternatywa, a nie uzupełnienie), choć oczywiście każdy przypadek należy rozpatrywać indywidualnie.

\section{Wnioski}

Celem niniejszego artykułu było ukazanie związku pomiędzy procesem suburbanizacji a powstawaniem nowych parafii. Na podstawie przeanalizowanego studium przypadku można stwierdzić, że w aglomeracji poznańskiej związek ten jest dość wyraźnie widoczny. Podczas gdy kilkanaście lat temu nowe parafie powstawały głównie na osiedlach wielkopłytowych, w ostatnich kilku latach tworzenie parafii miało miejsce głównie na obszarach podmiejskich. Można nawet postawić tezę, iż powstawanie na przedmieściach nowych miejsc kultu stanowi swego rodzaju specyfike procesu suburbanizacji w Polsce. Nie jest to zjawisko ani masowe, ani też marginalne, ale na pewno zauważalne.

Powstawanie nowych parafii na przedmieściach Poznania jest, jak można sądzić, konsekwencją realizacji przez archidiecezję poznańską określonej koncepcji rozwoju. Opiera się ona na założeniu, że dostępność przestrzenna świątyni ma znaczenie dla praktyk religijnych. Pytanie, na ile jest tak w istocie, mogłoby być przedmiotem interesujących badań socjologicznych. Zapewne część osób mimo wszystko zdecyduje się na uczestnictwo w praktykach religijnych w mieście - jeśli nie ze względu na bogatszą ofertę duszpasterską, to ze względu na przywiązanie do poprzedniej parafii. Z drugiej strony, dla pewnej części osób bliskość świątyni może być decydującym czynnikiem. W każdym razie, biorąc pod uwagę fakt, iż proces suburbanizacji w aglomeracji poznańskiej bynajmniej nie wygasa, prawdopodobne wydaje się powstanie kolejnych parafii na obszarach podmiejskich.

\section{Literatura}

Adamczuk L., Zdaniewicz W., Zaręba W., 2006, Statystyka diecezji Kościoła katolickiego $w$ Polsce 1992-2004, Instytut Statystyki Kościoła Katolickiego SAC, Warszawa.

Beim M., 2009, Modelowanie procesu suburbanizacji w aglomeracji poznańskiej, Bogucki Wydawnictwo Naukowe, Poznań. 
Domański B., Gwosdz K., Luchter L., 2005, Przestrzenne zróżnicowanie rozwoju sieci parafii w regionie przemysłowym, [w:] B. Domański, S. Skiba (red.), Geografia i sacrum, t. 2, IGiGP UJ, Kraków.

Draguła A., 2003, Między osiedlowym sklepem a supermarketem. Parafia w czasach wolnego rynku, „Więź”, nr 5 (535), http://www.wiez.pl/czasopismo/;s,czasopismo_ szczegoly,id,54,art,753 (dostęp 18.08.2014).

Firlit E., 2004, Parafia w społecznej świadomości, [w:] W. Zdaniewicz, S. Zaręba (red.), Kościół katolicki na początku trzeciego tysiąclecia w opinii Polaków, Instytut Statystyki Kościoła Katolickiego SAC, Warszawa, s. 143-175.

Jakóbczyk-Gryszkiewicz J., 1998, Przeobrażenia stref podmiejskich dużych miast. Studium porównawcze strefy podmiejskiej Warszawy, Łodzi i Krakowa, Wyd. UŁ, Łódź.

Kajdanek K., 2012, Suburbanizacja po polsku, Nomos Wyd. Naukowe, Kraków.

Klima E., 2011, Parafia jako przedmiot zainteresowania geografii - doświadczenia tódzkie, „Peregrinus Cracoviensis”, nr 22, s. 233-249.

Kubica H., 2006, Parafia przyszłości, „Przewodnik Katolicki”, nr 38.

Liszewski S., 1987, Strefa podmiejska jako przedmiot badan geograficznych. Próba syntezy, „Przegląd Geograficzny”, nr 59, s. 65-79.

Parysek J., 2008, Aglomeracje miejskie w Polsce oraz problemy ich funkcjonowania i rozwoju, [w:] J. Parysek, A. Tölle (red.), Wybrane problemy rozwoju i rewitalizacji miast: aspekty poznawcze i praktyczne, Bogucki Wyd. Naukowe, Poznań, (seria „Rozwój Regionalny i Polityka Regionalna”, nr 5), s. 29-48.

Swianiewicz P., Klimska U., 2005, Społeczne i polityczne zróżnicowanie aglomeracji w Polsce - waniliowe centrum, mozaika przedmieść, „Prace i Studia Geograficzne”, nr 35, s. 45-70.

Przybylska L., 2008, Zróżnicowanie przestrzeni sakralnej Gdyni, Wyd. Bernardinum, Gdynia-Pelplin.

Rocznik statystyczny Kościoła katolickiego w Polsce 1991-2011, 2014, GUS oraz Instytut Statystyki Kościoła Katolickiego SAC, Warszawa.

Strategia rozwoju aglomeracji poznańskiej. Metropolia Poznań 2020, 2011, http:// www.aglomeracja.poznan.pl (dostęp 18.08.2014).

Wykaz parafii $w$ Polsce, 2006, Instytut Statystyki Kościoła Katolickiego SAC, Warszawa.

\section{Storny internetowe}

www 1: http://www.archpoznan.pl/content/view/76/115/(dostęp 30.04.2014).

www 2: http://iskk.pl/kosciolnaswiecie/75-dominicantes.html, dostęp: 29.08.2014). 
www 3: http://www.kirche-im-rieselfeld.de/ (dostęp 19.08.2014).

www 4: http://driveinchurch.net, http://driveinchurch.org (dostęp 24.08.2014).

www 5: http://www.archpoznan.pl/content/view/311/123/(dostęp 18.08.2014).

www 6: http://www.parafialusowko.pl/index.php/o-parafii/historia-parafii (dostęp:

14.08.2014).

www 7: http://www.parafialusowko.pl/index.php/84-mieszkancu-lusowka (dostęp:

18.08.2014).

www 8: http://dabrowka.com.pl/pl/kim-jestesmy (dostęp: 18.08.2014).

www 9: http://m.poznan.gazeta.pl/poznan/56,106517,12306683,Nie_rozbudowujcie_Kosciola_murowanego_,,7.html (dostęp 18.08.2014).

www 10: http://mtkamionki.pl/?page_id=41 (dostęp 18.08.2014).

Adam Radzimski, dr

Wydziat Nauk Geograficznych i Geologicznych

Uniwersytet im. Adama Mickiewicza w Poznaniu

ul. Dzięgielowa 27, 61-680 Poznań

e-mail: adam.radzimski@amu.edu.pl 